\title{
Excuses, Excuses
}

\section{Rosena Brown Maghaberry Women's Prison}

This coming new year will no doubt bring with it the usual round of resolutions. We're going on a diet,' said a few of the girls at the start of this year. 'We're going to run every morning,' said the fitness fanatics. And the majority of smokers declared with great determination that they were most definitely quitting this time.

That was almost a year ago and, fair play to some of them, they've battled through it. I broke after a week, and may I say it was the worst week of my life. As a substitute for cigarettes, I stuffed myself with the remaining Christmas cakes and a half-a-pound of brandy balls, was violently ill, broke a tooth, and made everyone's life a misery with my short temper. No way, I'll die for Ireland any day as long as I have a fag in my hand.

Apart from all that, I couldn't think straight and when I listened to some of the others I found they had the same problem. Maire, an ardent smoker for the last twenty years, was looking for the tweezers, but instead asked if anyone had seen Ailish's eyebrows. Ailish, in the meantime, was talking back to front and informed us all that she was going to tumble dry her hair.

As for the ones on a diet, I caught them scoffing chocolates and drinking Coke. When I tackled them about it, I was told (in a very serious manner I may add) that it was Diet Coke and plain chocolates, not milk ones, as if this made an enormous difference. When I think of the fitness crew, the film The Loneliness of the Long Distance Runner comes to mind, and Rosie is out there come rain, hail, or shine. (Funnily enough, my sources in Long Kesh tell me that Ned Flynn is seen pounding the yard in the weeks before an inter-prison visit. Is there a connection? I ask myself.) The excuses from the others varied: 'It's too cold, 'I've a visit,' or 'I'm not well' were a few of them. But the excuse that took the biscuit (the one the dieters didn't actually eat, that is) came from Ann Marie who stated, 'I can't run this week, I've got a sore finger.' Ah well, Shauneen and Patricia are still doing their work-out to the over '50s video.

We all talked about it again and made firm decisions. The runners are definitely running after hallowe'en. The dieters are definitely dieting after Christmas, and I'm definitely stopping smoking come what may. As a matter of fact, it's top of my resolutions for ' 97 . 